\title{
Nietzsche and the Big Health. The Art as Culture's Therapy
}

\author{
Adilson Felicio Feiler* \\ Department of Philosophy's, Universidade do Vale do Rio dos Sinos, Brazil \\ *Corresponding author: Adilson Felicio Feiler, Philosophy's, Universidade do Vale do Rio dos Sinos, Brazil
}

\begin{tabular}{|c|c|}
\hline ARTICLE INFO & ABSTRACT \\
\hline & $\begin{array}{l}\text { Citation: Adilson Felicio Feiler. Nietzsche and the Big Health. The Art as Culture's } \\
\text { Therapy. Biomed J Sci \& Tech Res 36(2)-2021. BJSTR. MS.ID.005818. }\end{array}$ \\
\hline
\end{tabular}

\section{Mini Review}

The affirmative feeling to witch the Nietzsche's thought aim is marked by forces. These, when they act set in motion all sorts of oppositions and resistances. Thus, how bigger the urged opposition, so much bigger an employed resistance. This process strikes continuously and ever stronger, reaching points ever more culminating of power. For this reason, the German Philosopher brushes up the importance of life's conditions, of those who face the cutting air of highness, the winter hikes, the ice, the mountain-tops, every species of sublime wickedness. These resistance situations, when it acts in organism, generate a quantum ever stronger by its consequent overcoming. Living this overcoming is interject continuously resistance to limits and difficulties that show itself shaped big happening to mark the several return cycles. Soon, only the impetuous species, in physiology affirmative disposition, to be able to overcome, interchanging between the resistance and its prime experience, light, and jovial, as a rhythmic dance. These are the redeemer species, who have in the philosophy the art that cures the disease, who live the solitude not as escape, but as antidote powerful to promotion of the big health [1-5].

Large events, which mark humanity, constitute stages of the return cycle, and each stage leverages the game marked by opposition and resistance from which the forces that promote redemption arise. Humanity today lives, due to the pandemic, a new cycle of return. How could this great event serve as yet another redemptive antidote for humanity, in line with a rhythmic dance that leverages great health? Faced with this gigantic pandemic event, humanity suffers a frontal attack, aggressively attacking its fragile security guards. Like a biting wind, a winter walk and a steep peak, the pandemic shakes life in all its dimensions; be it the biological dimension, as well as the political, economic, social and spiritual dimension [6-11]. Life, understood organically, suffers failure in its capacity for breathing, since all the pores through which the air is communicated start to suffer obstruction; with this, the force is neutralized, as there is no enjoyment for the reception of vitality, nor discharge for the internal force to be externalized as creation.

Politically, life suffers, with the pandemic, an attack on its management structure. For, one does not invest in a global culture, but in national political madness, that is, a State that, instead of thinking of itself, should think of culture, a culture that favors strength. As a consequence of this self-centered State in a decadent authoritarianism, this great pandemic event causes impoverishment, since the creative forces are inhibited, and with this, without production there is no wealth, whose lack comes to be felt, in a special way, on the culture. The pandemic attack affects life in its social dimension, since the practice of isolation is felt as loneliness and the latter as an escape from reality. Although compulsory, social isolation could serve as a trigger for the great encounter with oneself, due to the capacity for self-affirmation. This impossibility of the effort to affirm oneself due to the pandemic, implies, finally, the spiritual emptying, and consequent denial in the formation of free spirits, those who would be able to overcome themselves, as affirmative psychological types [12-14].

In view of all the effects that the pandemic brings to life, threatening it in its capacity for affirmation and creation, we are 
led to investigate the intricacies of Nietzsche's physiology to find clues that help us to think about concrete ways of overcoming it. Therefore, the affirmation of life, through the overcoming of oppositions, occurs through docility at each major event of return, living in fullness, not with bitterness in the face of the heaviest weight, but with joy and dance, making the gravity of the great weight, lightness and affirmation. However, this disruption of weight is only possible from the disconnection of the herd and the cultivation of loneliness, not apathetic and headless loneliness, but a cultivator of oneself, through the affirming and therapeutic art of culture.

\section{References}

1. Behler Ernst (2017) Nietzsche no século XX. In: Nietzsche Bernd Magnuse Katheleen M (Org.) Trad. André Oides. Editora Ideias \& Letras: São Paulo.

2. Marta Sofia Ferreira Faustino (2013) Nietzsche e a grande saúde. Para uma terapia da terapia. Tese de Doutorado Lisboa.

3. Foucault Michel (2006) A hermenêutica do sujeito. Curso dado no Collège de France (1981-1982). Trad Márcio Alves da Fonseca e Salma Tannus Muchail. Martins Fontes: São Paulo.

4. Janz Curt (2015) Paul Friedrich Nietzsche. Uma biografia. Vol I: Infância Juventude, os anos em Basileia. Trad Markus A Hediger Vozes: Petrópolis.

ISSN: 2574-1241

DOI: 10.26717/BJSTR.2021.36.005818

Adilson Felicio Feiler. Biomed J Sci \& Tech Res

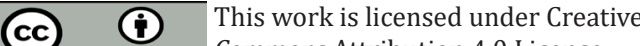

Commons Attribution 4.0 License

Submission Link: https://biomedres.us/submit-manuscript.php
5. Magnus Bernd, Higgins Katheleen M (2017) Introdução ao volume Nietzsche. In: Nietzsche Bernd Magnus e Katheleen M (Org.) Trad. André Oides. Editora Ideias \& Letras: São Paulo.

6. Nehamas Alexander (2017) Nietzsche, modernidade, esteticismo. In: Nietzsche Bernd Magnus e Katheleen M (Org.) Trad. André Oídes. Editora Ideias \& Letras: São Paulo.

7. Nietzsche F W (1999) (15 Bd) Kritische Studienausgabe. Herausgegeben von Giorgio Colli und Mazzino Montinari. Verlag de Gruyter: Berlin.

8. (1986) 8 Bd Sämtliche Briefe: Kritische Gesamtausgabe Briefwechsel KGB. Herausgegeben von Georgio Colli und Mazzino Montinari. Walter de Gruyter: Berlin.

9. (1987) Sócrates Xenofonte Ditos e feitos e feitos memoráveis de Sócrates Trad Libero Rangel de Andrade. Nova Cultural: São Paulo.

10. Schrift Alan D O (2017) legado francês de Nietzsche. In: Nietzsche. Bernd Magnus e Katheleen M (Org.). Trad. André Oídes. Editora Ideias \& Letras: São Paulo.

11. Stegmaier Werner (1994) Nietzsche's "Genealogie der Moral" Wissenschaftliche Buchgesellschaft: Darmstadt.

12. Oswaldo Giacoia (2013) As linhas fundamentais do pensamento de Nietzsche. Trad. Vozes: Petrópolis.

13. Woodward Ashley (2016) Nietzscheanismo Trad Diego Kosbiau Trevisan. Pensamento modern Vozes: Petrópolis.

14. Wotling Patrick (2008) La Culture comme problème. La Redetermination Nietzscheenne du Questionnement Philosophique. Nietzsche Studien 37(1): $1-50$.

$\begin{array}{ll}\text { BIOMEDICAL } & \text { Assets of Publishing with us } \\ \text { RESEARCHES } & \text { - Global archiving of articles } \\ \text { - Immediate, unrestricted online access }\end{array}$

